Makale türü / Article type: Araştırma / Research

\title{
Hemşirelik Öğrencilerinin İletişim Becerilerinin Değerlendirilmesi ${ }^{1}$ $* * *$
}

\section{An Assessment of Communication Skills of Nursing Students ${ }^{2}$}

\author{
Öğr. Aysun Akçam (MSc) \\ Ahi Evran Üniversitesi, akcamaysun1@gmail.com \\ (ORCID No: 0000-0001-9428-3942) \\ Dr. Öğr. Üyesi Yalçın Kanbay \\ Artvin Çoruh Üniversitesi Sağllk Bilimleri Fakültesi, yalcinkanbay@ hotmail.com \\ (ORCID No: 0000-0002-8025-9877) \\ Dr. Öğr. Üyesi Elif Işık \\ Artvin Çoruh Üniversitesi, Sağlık Bilimleri Fakültesi, elifsyo@gmail.com \\ (ORCID No: 0000-0001-7071-7654)
}

\begin{abstract}
Özet
Çalışma iletişim becerileri ve etkileyen etmenlerin değerlendirilmesi amacı ile 20182019 eğitim öğretim y1lı bahar yarıyllnnda, üniversite 1.(n:79) ve 4.(n:56) sınıf öğrencilerinde, iletişim beceri gelişimini irdelemek amacı ile yürütülmüştür. Veriler, "Kişisel Bilgi Formu" ve "İletişim Becerilerini Değerlendirme Ölçeği (IBBDÖ)" kullanılarak toplanmıştır. Çalışmada non-parametrik testler kullanılmıştır. 1. sınıfların İBDÖ puanları ortalaması $101.2 \pm 1.286$ puan iken, 4. sinıfların ortalaması $98.8 \pm$ 1.414 puan olarak hesaplanmıştır. Örneklemin genelinde ise İBDÖ puanı 68 ile 123 arasında değişmekte olup örneklem ortalaması $100.2 \pm .956$ puandır. Öğrencilerin İBDÖ puan ortalamaları sınıfa göre farklılık göstermemektedir. Kız öğrencilerin iletişim becerisi erkeklerden anlamlı düzeyde yüksek bulunmuştur. Yaş, aile tipi, anne eğitimi, baba eğitimi ve yaşanılan yer gibi değişkenlerin iletişim becerisi üzerinde etkisiz olduğu belirlenmiştir.
\end{abstract}

\footnotetext{
${ }^{1} \mathrm{Bu}$ çalışma UMTEB 6. Uluslararası Mesleki ve Teknik Bilimler Kongresi, 11-12 Nisan 2019, Iğdır kongresinde Sözlü Bildiri olarak sunulmuştur.

${ }^{2}$ This study was presented as the Oral Presentation at UMTEB 6th International Vocational and Technical Sciences Congress, 11-12 April 2019, Iğdır Congress.
} 
Anahtar kelimeler: İletişim, iletişim becerisi, üniversite öğrencileri JEL Sinıflandırması: D83

\begin{abstract}
The study was conducted in the spring semester of the 2018-2019 academic year with the aim of evaluating the communication skills and the factors affecting the communication skills development in the $1^{\text {st }}$ and $4^{\text {th }}$ grade students of the university. Data were collected using "Personal Information Form" and "Communication Skills Assessment Scale". 1. The mean scores of the classes were 101.2 \pm 1.286 and $98.8 \pm$ 1.414 , respectively. In the whole sample, the SANS score ranged between 68 and 123, with a mean of $100.2 \pm .956$. The communication skills of female students were found to be significantly higher than the male students. The variables such as age, type, mother education, father education and place of residence were found to be ineffective on communication skills.
\end{abstract}

Keywords: Communication, communication skills, university students JEL Classification: D83

\title{
GİRIŞ̧
}

Sosyal bir varlık olan ve var oluşundan itibaren çevresiyle sürekli etkileşim içerisinde bulunan insanoğlu (Tayfun, 2014, s. 3), duygularını ve düşüncelerini aktarma gereksinimini konuşarak ve yazarak gidermeye çalışmış, bu sayede konuştuklarının dinleme, yazdıklarının ise okuma yoluyla anlaşılmasını istemiştir. İnsanoğlunun bu istek ve gereksinimine bağlı olarak da iletişim denen olgu ortaya çıkmıştır (Çetinkaya, 2011; Tutar ve Yılmaz, 2010, s. 15). Bilgi üretme, aktarma ve anlamlandırmanın yanı sıra, insanın doğasında var olan kendini anlatma ve başkalarını anlama ihtiyacı, bireyleri birbirleriyle iletişim kurmaya itmiştir (Dökmen, 1994, s. 13; Cüceloğlu, 2000).

"Ortaklık, toplumsallaşma, birliktelik" gibi kavramları ifade eden iletişim kavramı, bireylerin biyolojik bir varlıktan sosyal bir varlığa dönüşmesini sağlayan önemli bir unsur, ayrıca onların meramını anlatmak için başvurduğu yöntem ve tekniklerin tümünü kapsayan çok boyutlu bir kavramdır (Erdoğan, 2002; İnceoğlu, 2004; Üstün, Akgün ve Partlak, 2005, s. 
10-11; Çamdereli, 2008; Taymaz, 2011, s. 42; Küçük, 2012; Çağlar ve Kılıç, 2012, s. 3).

"Enformasyon çağı" olarak da adlandırılan günümüzde, hızla ilerleyen teknolojik gelişmelere paralel olarak insanlar arasındaki iletişimin hızı da artmakta, gönderici ve alıcılar arasındaki iletiler yoğunluk kazanmaktadır. İnsanoğlunun, bilginin hızla yayıldığı bu çağa ayak uydurabilmesi ve toplumsal düzen içinde yerini alarak sosyalleşebilmesi için, sahip olduğu bu iletişim kurabilme özelliğini geliştirmesi ve etkin bir şekilde kullanabilmesi gereklidir (Başaran, 1999, s. 17).

Kimi zaman insanlar arasındaki anlam alışverişi (Cüceloğlu, 2016), kimi zaman toplumsal ve bireysel varlı̆̆ımızın bilincine varmanın bir yolu (Zıllığlu, 1996, s.44), kimi zaman ise bireysel varlığın bir zorunluluğu, ayrıcalığı ve önceliği olarak ifade edilen ve kaynağın alıcıya mesaj göndermesiyle başlayan bu kavram (Erdoğan ve Alemdar, 1990, s. 170; Usluata, 1995; Baran, 1997, s. 13; Oskay, 1999; Başaran, 2000, s. 267) günümüz dünyasında meslekî becerilerin de önemli bir boyutunu oluşturmaktadır. İletişim becerilerinin geliştirilmesi, merkezinde insanlarla kurulan sağlıklı ilişkilerin bulunduğu hemşirelik mesleği için de oldukça önem arz eder. Bu becerilerin geliştirilmesi hemşirelik eğitiminde temel (core) hedefler arasındadır. Kayıkçı (2001, s. 52)'nın tüm sorunlarla uğraşma aracı olarak tanımladığı iletişim, güçlü bir terapötik araçtır ve pozitif sağlık sonuçlarına ulaşmak ve başkalarını etkilemek için kullanılan gerekli bir hemşirelik becerisidir (Üstün, Akgün ve Partlak, 2005). Dolayısıyla üniversitelerin Hemşirelik bölümünde öğrenim gören bireylerin iletişim becerilerinin ne düzeyde ve ne şekilde olduğunun araştırılması ve elde edilen bulgular doğrultusunda ise, onların iletişim becerilerinin daha da geliştirilmesi amaçlanmalı ve paralelinde gerekli çalışmalar yürütülmelidir.

$\mathrm{Bu}$ nedenle iletişim becerilerinin önemli olduğu ve yoğun olarak kullanıldığı bir meslek olan hemşirelik mesleğinin gelecekteki mensupları olacak hemşirelik öğrencilerinin iletişim becerilerinin incelendiği bu çalışma plânlanmış ve literatüre katkı sağlaması amaçlanmıştır. 


\section{GEREÇ VE YÖNTEM}

\subsection{Araştırmanın Tipi}

Araştırma tanımlayıcı tipte bir çalışmadır.

\subsection{Araştırmanın Yapıldığı Yer ve Zaman}

Bu çalışma 2018-2019 eğitim öğretim yılı bahar döneminde Artvin Çoruh Üniversitesi Sağlık Bilimleri Fakültesinde (AÇÜ-SBF) yürütülmüştür.

\subsection{Evren ve Örneklem}

Çalışmanın evrenini AÇÜ-SBF Hemşirelik bölümü 1. ve 4. sınıf öğrencileri oluşturmuştur. Bu çalışmanın amacı, verilen lisans eğitiminin ve müfredatın öğrencilerin iletişim becerileri üzerindeki etkisini incelemek olduğundan çalışmaya sadece 1 ve 4. sınıflar alınmıştır. 2018-2019 eğitim öğretim yılında AÇÜ-SBF hemşirelik bölümünde kayıtlı öğrenci sayısı hem 1. sınıflar için hem de 4. sınıflar için 82'dir (YÖKSİS, 2019). Çalışmanın amacina uygun olarak 1. ve 4. sınıfta okuyan bütün öğrenciler çalışma kapsamına alınmış ancak ulaşılamayan, çalışmaya katılmak istemeyen ya da veri toplama formlarına eksik cevaplar veren öğrenciler olması nedeni ile 79'u 1. sınıf ve 56'sı 4. sınıf öğrencisi olmak üzere toplam 135 öğrenci çalışmanın örneklemini oluşturmuştur.

\subsection{Verilerin Toplanması}

Veriler araştırmacılar tarafından yüz yüze görüşme yöntemi ile toplanmıştır. Öğrencilerin uygun oldukları bir zaman diliminde öğrenciler ile görüşülerek çalışmanın amacı açıklanmış ve çalışma hakkında bilgilendirilerek katılmak isteyenlerin sözlü olurları alınmıştır. Daha sonra çalışmaya katılmak istediğini belirten öğrencilere veri toplama formları dağıtılarak veri toplama formlarını cevaplandırmaları istenmiştir.

\subsection{Veri Toplama Araçları}

Çalışmanın veri toplama aşamasında "Kişisel Bilgi Formu" ve "İletişim Becerilerini Değerlendirme Ölçeği” kullanılmıştır. 


\subsubsection{Kişisel Bilgi Formu}

Katılımcılara ait çeşitli demografik özelliklerinin sorgulandığı veri toplama formudur.

\subsection{2. İletişim Becerilerini Değerlendirme Ölçeği (İBDÖ)}

Bireylerin iletişim becerilerini nasıl değerlendirdiklerini anlamak amacı ile geliştirilmiştir. İBDÖ, 25 ifadeden oluşan 5'li likert tipte bir ölçektir. Ölçek maddeleri hiçbir zamandan (1) her zamana (5) doğru puanlanmaktadır. Tersine maddelerin olmadığı ölçekten elde edilen puanın fazlalığı bireylerin kendi iletişim becerilerini olumlu yönde değerlendirdikleri anlamına gelmektedir. Testin tekrarı yöntemi ile yapılan güvenirlik çalışması sonucunda ölçeğin güvenirlik katsayısı $0.76(\mathrm{p}<.001)$ olarak elde edilmiştir. İç tutarlılık katsayısı olarak Cronbach Alpha değeri ise 0.80 ( $p<.001)$ olarak bulunmuştur (Korkut, 1996). Bu çalışmada ise ölçeğin Cronbach Alpha değeri 0.88 olarak hesaplanmıştır.

\subsection{Verilerin Değerlendirilmesi}

Uygulanacak analizlere karar verebilmek için çalışma verileri normallik sınamasına tabi tutulmuştur. Test sonucunda puanların normallik varsayımını sağlamadığ1 görülmüş ve bu nedenle karşılaştırmalarında Non parametrik testler kullanılmıştır. Bu çerçevede verilerin analizi SPSS 23.0 ortamında; sayı, ortalama, yüzde, Mann Whitney U testi ve Kruskal Wallis H testi kullanılarak değerlendirilmiştir.

\subsection{Araştırmanın Etik Yönü}

Çalışma öncesi Artvin Çoruh Üniversitesi Etik Kurulundan etik kurul onayı, çalışmanın yürütüldüğü kurumlardan yazılı izin, katılımcılardan ise bilgilendirilmiş onam alınmıştır.

\section{BULGULAR}

Araştırmanın verilerinden elde edilen bulgular aşağıda sunulmuştur. 
Tablo 1: Örnekleme ilişkin demografik veriler

\begin{tabular}{llll}
\hline Değişken & & $\mathbf{n}$ & Yüzde (\%) \\
\hline \multirow{2}{*}{ Sınıf } & 1 & 79 & 58.5 \\
& 4 & 56 & 41.5 \\
Cinsiyet & Kadın & 86 & 63.7 \\
& Erkek & 49 & 36.3 \\
Yaş & 20 ve altı & 69 & 51.1 \\
\multirow{3}{*}{ Aile tipi } & 21 ve üstü & 66 & 8.9 \\
& Çekirdek & 105 & 77.8 \\
Anne eğitimi & Geniş & 30 & 22.2 \\
& İlköğretim & 116 & 85.9 \\
& Ortaöğretim & 10 & 7.4 \\
Baba eğitimi & Yükseköğretim & 9 & 6.7 \\
& İlköğretim & 97 & 71.9 \\
& Ortaöğretim & 28 & 20.7 \\
Yaşadığı yer & Yükseköğretim & 10 & 7.4 \\
& Köy & 34 & 25.2 \\
& İlçe & 40 & 29.6 \\
\hline
\end{tabular}

Tablo 1'deki verilere göre, örneklemin $\% 58.5$ 'i 1. sinıf öğrencilerden oluşurken $\% 41.5$ ' $\mathrm{i}$ ise 4 . sınıf öğrencilerden oluşmaktadır. \%63.7'si kadınlardan oluşan örneklemin yaş ortalaması $20.7 \pm .165$ olarak hesaplanmıştır. Bu nedenle örneklem 20 yaş ve altı (\%51.1) ile 21 yaş ve üstü (\%48.9) şeklinde iki gruba ayrılmıştır. Çekirdek aileye sahip öğrencilerin oranı \%77.8 iken, geniş aileye sahip öğrencilerin oranı \%22.2'dir. Öğrencilerin büyük bölümünün anne eğitim düzeyi (\%85.9) ve baba eğitim düzeyi (\%71.9) ilköğretimdir. Öğrencilerin 25.2'si köyde yaşarken, \%29.6's1 ilçede ve \%45.2'si ise şehirde yaşamaktadır. 


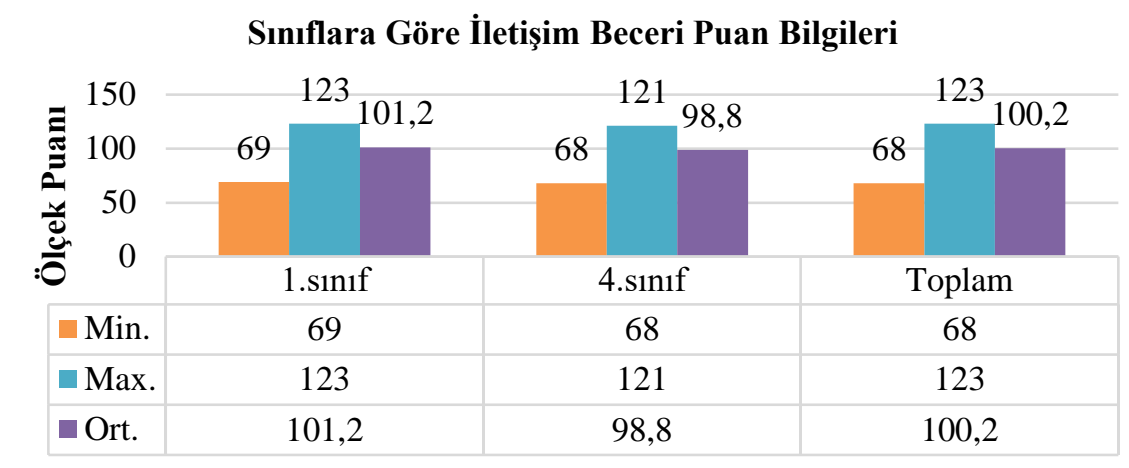

Şekil 1: Sınıflara ait İBDÖ puanlarına ilişkin bulgular

Öğrencilerin iletişim beceri puanları Şekil 1'de incelenmiştir. Buna göre, 1. sınıfların İBDÖ puanları 69 ile 123 arasında değişmekte olup 1. sınıflar için İBDÖ puan ortalaması 101.2 1.286 puan olarak hesaplanmıştır. 4. sınıfların İBDÖ puanları 68 ile 121 arasında değişirken bu sınıfa ait İBDÖ ortalaması $98.8 \pm 1.414$ puan olarak belirlenmiştir. Örneklemin genelinde ise İBDÖ puanı 68 ile 123 arasında değişmekte olup örneklem ortalaması 100.2 \pm .956 puan olarak hesaplanmıştır.

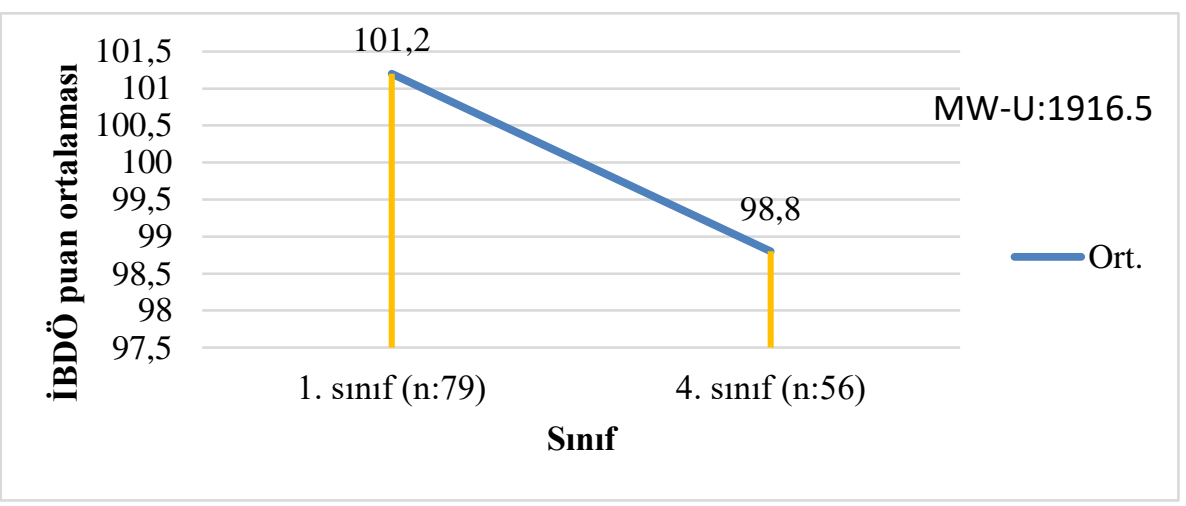

Şekil 2: Sınıflara göre İBDÖ puan ortalaması karşılaştırması

Öğrencilerin sınıflara göre İBDÖ puan ortalamaları Şekil 2'de verilmiştir. 1. sınıfta öğrenim gören öğrencilerin İBDÖ puan ortalaması 100.2 \pm 1.286 puan iken, 4 . sınıfta öğrenim gören öğrencilerin puan ortalaması 98.8 
\pm 1.414 puandır. 1. sınıf öğrencilerin İBDÖ puan ortalaması 4. sinıfların ortalamasından yüksek olmasına karşın aradaki farkın istatistiksel olarak anlamlı olmadığı belirlenmiştir ( $>>0.05$ ). Bu bulguya göre öğrencilerin İBDÖ puan ortalamaları sınıfa göre farklılık göstermemektedir ve iletişim becerileri benzer düzeydedir.

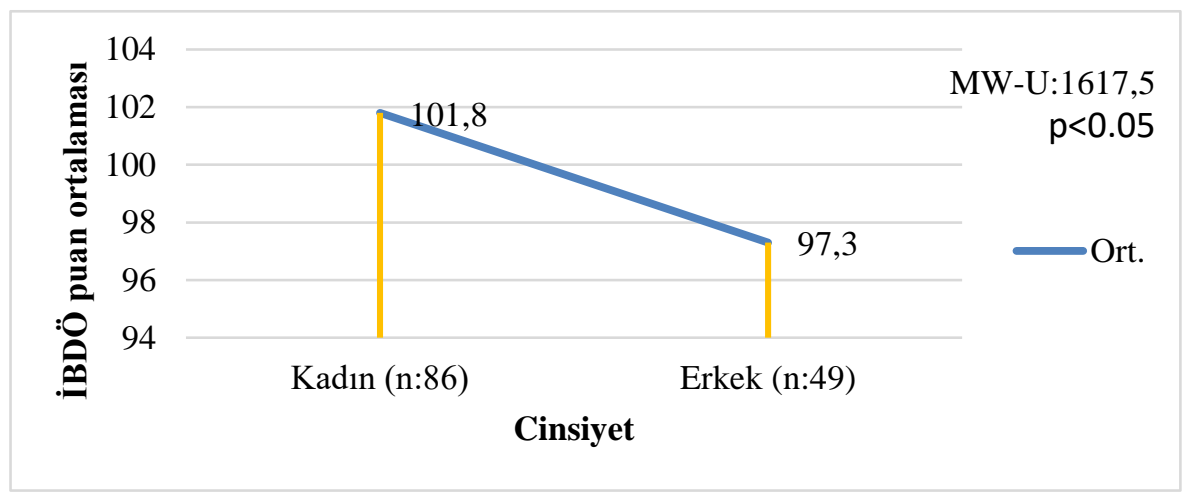

Şekil 3: Cinsiyete göre İBDÖ puan ortalaması karşılaş̧ırması

Öğrencilerin cinsiyete göre İBDÖ puan ortalamaları Şekil 3'te

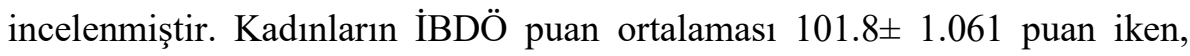
erkeklerin puan ortalaması $97.3 \pm 1.805$ puan olarak belirlenmiş olup iki ortalama arasındaki farkın istatistiksel olarak birbirinden farklı olduğu belirlenmiştir $(p<0.05)$. Bu bulguya göre kadınların İBDÖ puan ortalaması erkeklerin puan ortalamasından anlamlı derecede yüksektir.

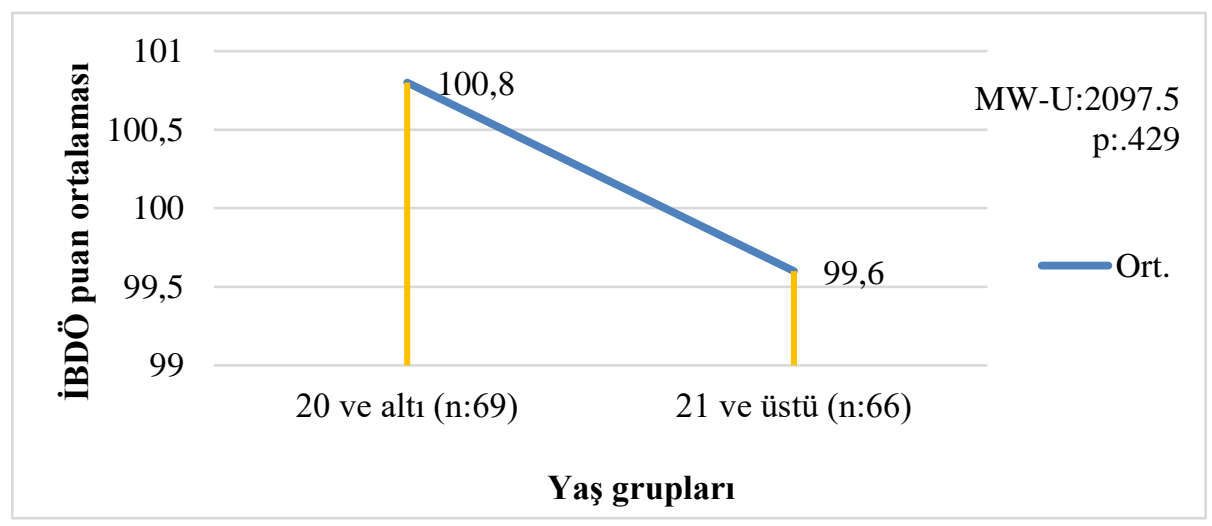

Şekil 4: Yaş gruplarına göre İBDÖ puan ortalaması karşılaştırması 
Öğrencilerin yaşlarına göre İBDB puan ortalamaları Şekil 4'te verilmiştir. Buna göre, 20 yaş ve altı yaşa sahip grubun İBDÖ puan ortalaması $100.8 \pm 1.372$ puan iken, 21 yaş ve üstü yaşa sahip grubun puan ortalaması $99.6 \pm 1.335$ puan olarak belirlenmiş olup iki ortalama arasındaki farkın istatistiksel olarak birbirine benzer olduğu belirlenmiştir ( $\mathrm{p}>0.05)$. Bu bulguya göre öğrencilerin yaş gruplarına göre İBDÖ puan ortalamaları farklılık göstermemektedir.

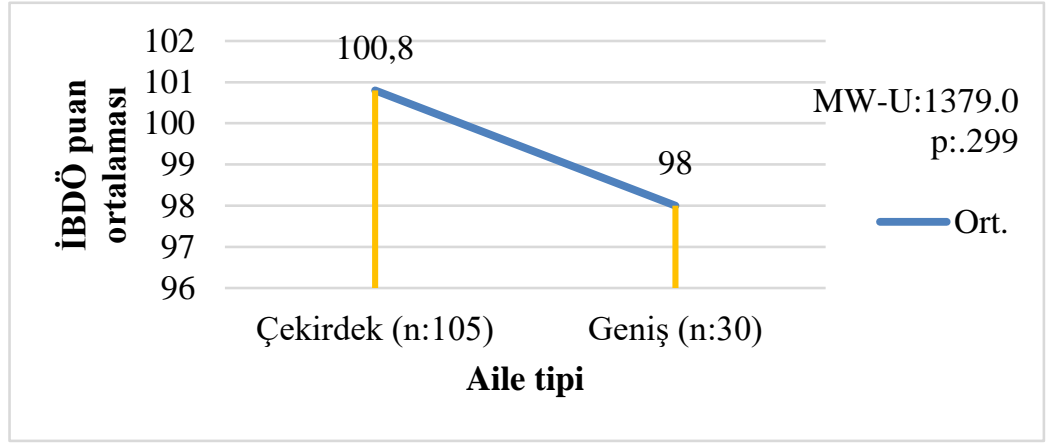

Şekil 5: Aile tipine göre İBDÖ puan ortalaması karşılaştırması

Öğrencilerin aile tipine göre İBDÖ puan ortalamaları Şekil 5'te karşılaştırılmıştır. Çekirdek aileye sahip grubun İBDÖ puan ortalaması 100.8 \pm 1.081 puan iken, geniş aileye sahip grubun puan ortalamas1 $98.0 \pm 2.029$ puan olarak belirlenmiş olup, iki ortalama arasındaki farkın istatistiksel olarak anlamsız olduğu belirlenmiştir ( $p>0.05$ ). Öğrencilerin çekirdek aileye ya da geniş aileye sahip olması İBDÖ puan ortalaması üzerine etkisiz bulunmuştur.

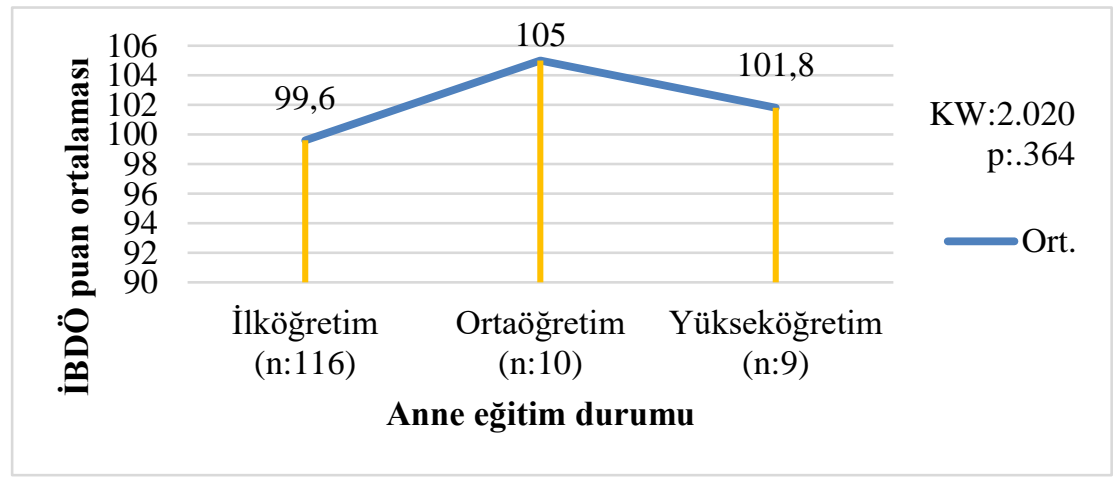


Şekil 6: Anne eğitim durumuna göre İBDÖ puan ortalaması karşılaştırması

Anne eğitim durumuna göre öğrencilerin İBDÖ puan ortalamalarının karşılaştırılması Şekil 6'da verilmiştir. Anne eğitim durumu ilköğretim olan grubun İBDÖ puan ortalaması $99.6 \pm 1.037$ puan iken, ortaöğretim olan grubun $105.0 \pm 3.568$ puan ve yükseköğretim olan grubun ise $101.8 \pm 3.244$ puan olarak belirlenmiştir. Anne eğitim durumuna göre İBDÖ puan ortalaması yüksekten düşüğe doğru ortaöğretim, yükseköğretim ve ilköğretim şeklinde siralanmakla birlikte gruplar arasındaki farkın istatistiksel olarak anlamsız olduğu belirlenmiştir $(\mathrm{p}>0.05)$. Bu bulguya göre anne eğitim durumu öğrencilerin iletişim becerilerini değerlendirmede etkisiz bulunmuştur.

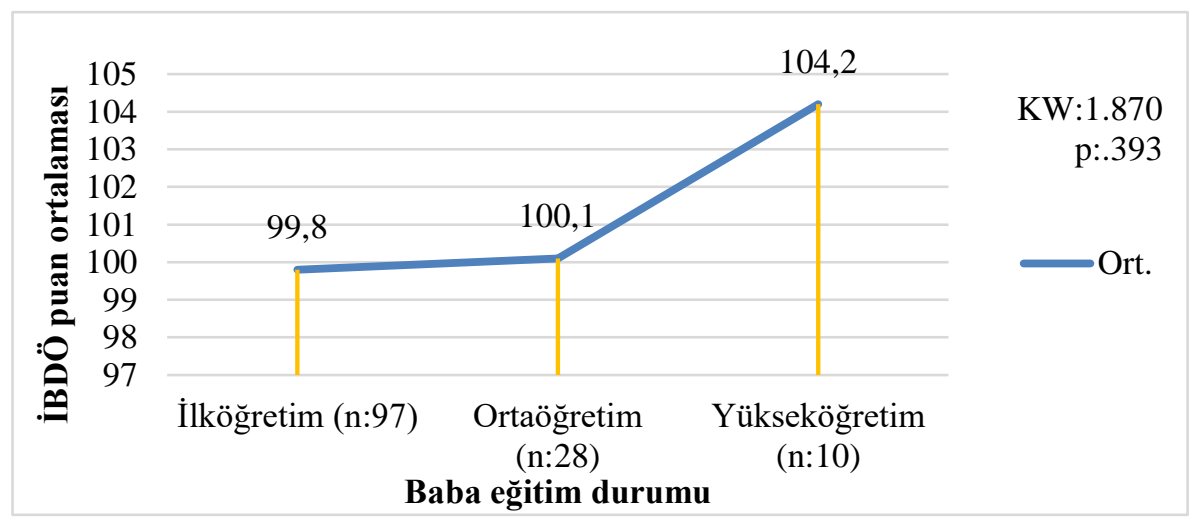

Şekil 7: Baba eğitim durumuna göre İBDÖ puan ortalaması karşılaştırması

Baba eğitim durumuna göre öğrencilerin İBDÖ puan ortalamalarının karşılaştırılması Şekil 7'de verilmiştir. Baba eğitim durumu ilköğretim olan grubun İBDÖ puan ortalaması $99.8 \pm 1.047$ puan iken, ortaöğretim olan grubun $100.1 \pm 2.709$ puan ve yükseköğretim olan grubun ise $104.2 \pm 2.577$ 
puan olarak belirlenmiştir. Baba eğitim durumuna göre İBDÖ puan ortalamas1 yüksekten düşüğe doğru yükseköğretim, ortaöğretim ve ilköğretim şeklinde sıralanmakla birlikte gruplar arasındaki farkın istatistiksel olarak anlamsız olduğu belirlenmiştir ( $p>0.05)$. Baba eğitim durumu öğrencilerin iletişim becerilerini değerlendirmede etkisiz bulunmuştur.

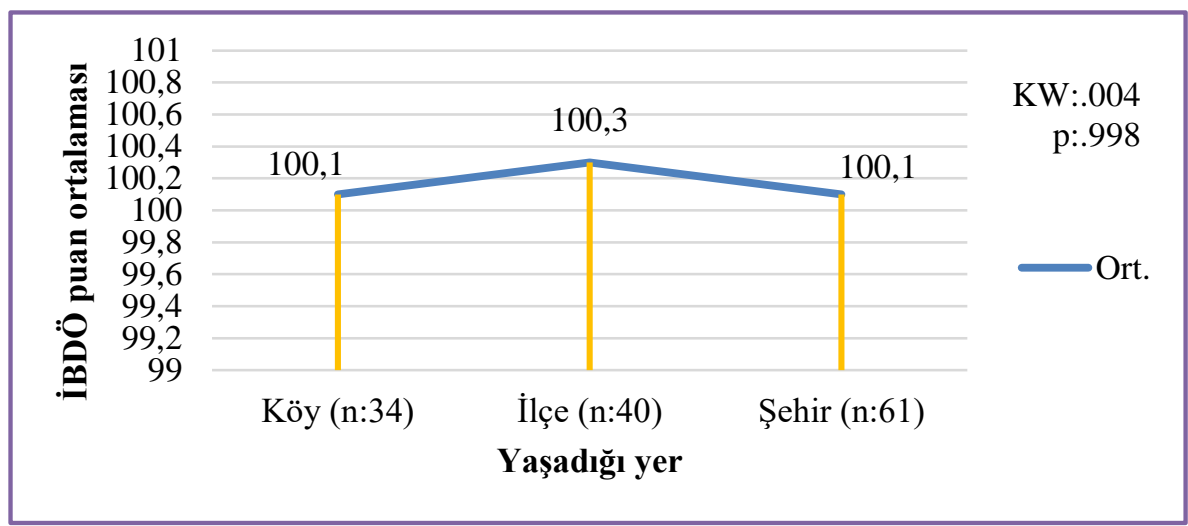

Şekil 8: Yaşadığı yere göre İBDÖ puan ortalaması karşılaştırması

Öğrencilerin yaşadıkları yere göre İBDÖ puan ortalamalarının karşıllaştırılması Şekil 8'de verilmiştir. Köyde yaşayan grubun İBDÖ puan ortalaması $100.1 \pm 1.691$ puan iken, ilçede yaşayan grubun $100.3 \pm 1.865$ puan ve şehirde yaşayanların ise $100.1 \pm 1.468$ puan olarak belirlenmiştir. Öğrencilerin İBDÖ puan ortalamaları yaşadığı yere göre istatistiksel olarak anlamlı bir farklılık göstermemektedir ( $\mathrm{p}>0.05)$. Bu bulguya göre yaşanılan yer iletişim becerisi üzerinde etkisiz bulunmuştur.

\section{TARTIŞMA}

Bu bölümde üniversite öğrencilerinin iletişim beceri düzeylerinin sınıf düzeyi, cinsiyet, yaş grubu, aile tipi, anne-baba eğitim durumu ve yaşadığı yer bakımından değişip değiş̧mediğine dair bulgular literatürden faydalanılarak yorumlanmış ve tartışılmıştır.

Araştırmaya katılan öğrencilerin İletişim Becerilerini Değerlendirme Ölçeği (IBDÖ) puan ortalaması incelendiğinde; örneklemin genelinde İBDÖ 
puanı 68 ile 123 arasında değişmekte olup örneklem ortalaması 100.2 \pm .956 puan olarak hesaplanmıştır (Şekil 1).

Ölçeği geliştiren ve geçerlik ve güvenirlik çalışmasını yapan Korkut (1996), ölçekten elde edilen puanın fazlalığının bireylerin kendi iletişim becerilerini olumlu yönde değerlendirdikleri anlamına geldiğini belirtmiştir (Korkut, 2005). Elde edilen sonuçlar, çalışmaya katılan öğrencilerin iletişim becerilerini değerlendirme ölçeği puan ortalamasının yüksek olduğunu, dolayısıyla çalışmaya katılan öğrencilerin iletişim becerilerinin iyi düzeyde olduğunu göstermektedir.

Çalışmaya katılan öğrencilerin iletişim becerileri sınıf düzeyine göre değerlendirildiğinde, 1. sınıfta öğrenim gören öğrencilerin İBDÖ puan ortalaması $100.2 \pm 1.286 \mathrm{iken,} \mathrm{4.} \mathrm{sınıfta} \mathrm{öğrenim} \mathrm{gören} \mathrm{öğrencilerin} \mathrm{puan}$ ortalaması $98.8 \pm 1.414$ ' tür. 1 . sınıf öğrencilerinin İBDÖ puan ortalaması 4. sınıfların ortalamasından yüksek olmasına karşın aradaki farkın istatistiksel olarak anlamlı olmadığı saptanmıştır ( $>0.05$ ) (Şekil 2). Buna göre; sınıf düzeyi arttıkça öğrencilerdeki iletişim becerilerinin de daha fazla gelişim göstermesi beklenmekteyken, öğrencilerin İBDÖ puan ortalamalarının sınıf düzeyine göre farkl111k göstermediği ve iletişim becerilerinin benzer düzeyde olduğu ortaya çıkmıştır. Çalışma bulgusu ile benzer şekilde, Ülker (2016)'in meslek yüksekokulu öğrencileri ile yaptığ çalışmada, İletişim Becerileri Envanterinin alt boyutlarından ve ölçeğin tamamından alınan toplam puanların sınıf düzeyine göre farklılaşmadığı, yani birinci sınıfta öğrenim gören öğrencilerin iletişim becerileri envanterinden aldıkları puanların ikinci sınıfta öğrenim görenlere göre anlamlı bir farklılaşma göstermediği tespit edilmiştir. Baykara Pehlivan (2005)'ın öğretmen adayları ile yaptığı çalışmada ise çalışma bulgusunun aksine, adayların iletişim becerisi algılarının ortalamaları, 1. sınıftan 4. sınıfa doğru anlamlı şekilde artış göstermektedir.

Çalışmaya katılan öğrenciler cinsiyete göre değerlendirildiğinde, kız

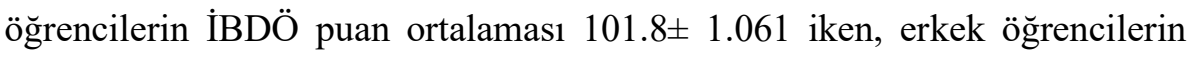
puan ortalaması $97.3 \pm 1.805^{\prime}$ tir ve bu iki ortalama arasındaki farkın istatistiksel olarak birbirinden farklı olduğu belirlenmiştir $(\mathrm{p}<0.05)$ (Şekil 3). Buna göre; İBDÖ puan ortalaması erkeklerin puan ortalamasından anlamlı derecede daha yüksek bulunan kız öğrencilerin iletişim becerileri daha fazla 
gelişmiştir. $\mathrm{Bu}$ bulgunun, kız çocuklarının gelişim özelliklerinin erkek çocuklarına kıyasla daha farklı olmasından kaynaklandığı düşünülmektedir. Çalışma bulgusu ile benzer şekilde, Ökten (2019)'in, hemşirelerin duygusal zekâ düzeyleri ile iletişim becerileri arasındaki ilişkinin incelenmesi adlı çalışmasında da kadın katılımcıların davranışsal iletişim becerilerinin erkek katılımcılara göre anlamlı bir şekilde daha yüksek olduğu belirlenmiştir. Çalışma bulgusunun aksine, Acar (2009)'ın öğretmen adayları ile yaptığı çalışmada, adayların cinsiyete göre iletişim becerileri ölçeği toplam puanlarının ortalamaları arasında anlamlı fark bulunmamıştır. Fakat iletişim becerileri alt boyutlarından, "Davranışsal" alt boyutunda cinsiyete göre anlamlı bir fark bulunmuştur. Bu fark ise, çalışma bulgumuzun aksine erkek öğretmen adaylarının lehinedir. Benzer şekilde, Akbal (2008)'ın okul yöneticileri ile yaptığı çalışmada uygulanan T-testi sonucuna göre, yöneticilerin iletişim becerileri cinsiyet değişkenine göre farklılık göstermemiştir. Akbaş (2018)'in özel okullarda okul yöneticileri ve branş öğretmenleri ile yaptığı çalışmada da branş öğretmenlerinin yöneticilerinin zihinsel, duygusal ve davranışsal iletişim beceri düzeyleri hakkındaki değerlendirmelerinin kadın ve erkek öğretmenler arasında anlamlı bir farklılık göstermediği saptanmıştır. Benzer şekilde, Ceylan (2017)'ın okul öncesi öğretmenleri ile yaptığı çalışmada, çalışma grubunun cinsiyet değişkenine göre iletişim becerilerinin ve alt boyutlarının farklılaşmadığı saptanmıştır. Aynı şekilde Albayrak (2019)'ın Sivas Numune Hastanesi'nde çalışan hemşirelerin iletişim becerilerinin motivasyon ve tükenmişlik düzeyine etkisini araştırdığı çalışmada da cinsiyet değişkeni ile iletişim becerileri envanteri arasında istatistiksel olarak anlamlı bir farklılık görülmemiştir. Çoraklı (2019)'nın hemşirelerin iletişim becerilerinin incelenmesi adlı çalışmasında da katılımcıların iletişim becerisi genel puanları cinsiyet değişkenine göre anlamlı farklılık göstermemektedir. Duran (2019), sağlık çalışanlarının iletişim becerilerini ve göçmenlerle yaşadıkları iletişim zorluklarını belirlediği çalışmada da benzer bir sonuca ulaşmış ve cinsiyet değişkeni ile bireylerin iletişim becerileri arasında anlamlı bir fark olmadığını belirlemiştir.

Öğrenciler yaş gruplarına göre değerlendirildiğinde, 20 ve altında yaş grubuna sahip öğrencilerin İBDÖ puan ortalaması $100.8 \pm 1.372$ iken, 21 ve 
üzeri yaş grubuna sahip öğrencilerin puan ortalaması $99.6 \pm 1.335$ 'tir ve iki ortalama arasındaki farkın istatistiksel olarak birbirine benzer olduğu belirlenmiştir ( $>>0.05)$ (Şekil 4). Buna göre; yaş düzeyi arttıkça öğrencilerdeki iletişim becerilerinin de daha fazla gelişim göstermesi beklenmekteyken, öğrencilerin yaş gruplarına göre İBDÖ puan ortalamaları farklılık göstermemektedir. Çalışma bulgusu ile benzer şekilde, Akbal (2008)'ın okul yöneticileri ile yaptı̆̆ çalışmada, yöneticilerin iletişim becerileri yaşa göre farkl1lı göstermemekle birlikte, bu bulgunun katılımcıların yaş ortalamasının yetişkin yaş grubu içinde yer almasından kaynaklanabileceği düşünülmektedir. Aynı şekilde, Köleşoğlu (2009)'nun ilköğretim öğretmenleriyle yaptığı çalışmada da öğretmenlerin iletişim becerilerinin yaşlarına göre farkl11ık göstermediği sonucuna ulaşılmıştır. Benzer şekilde, Çelik (2007)'in ilköğretim okulu müdürleri ile yaptığ1 çalışmada, müdürlerin yaşları ile kendi iletişim becerilerini değerlendirmeleri arasında anlamlı bir farklılık görülmemiştir. Albayrak (2019)'ın Sivas Numune Hastanesi'nde çalışan hemşirelerin iletişim becerilerinin motivasyon ve tükenmişlik düzeyine etkisini araştırdığı çalışmada da yaş değişkeni ile iletişim becerileri envanteri arasında istatistiksel olarak anlamlı bir farklılık görülmemiştir. Ökten (2019)'in, hemşirelerin duygusal zekâ düzeyleri ile iletişim becerileri arasındaki ilişkinin incelenmesi adlı çalışmasında da katılımcıların yaşları ile iletişim becerileri envanteri alt boyutları arasında anlamlı bir ilişkinin olmadığı ortaya konulmuştur. Çoraklı (2019)'nın hemşirelerin iletişim becerilerinin incelenmesi adlı çalışmasında da katılımcıların iletişim becerisi genel puanları yaş grubu değişkenine göre anlamlı farkl11ık göstermemektedir. Çalışma bulgusunun aksine, Ceylan (2017)'ın okul öncesi öğretmenleri ile yaptığı çalışmada, öğretmenlerin iletişim beceri düzeylerinin yaş değişkenine göre farklılaştığı ve bu farklılığın 41 ve üzeri yaş grubu lehine olduğu bulunmuştur.

Çalışmaya katılan öğrenciler aile tipine göre değerlendirildiğinde, çekirdek aileye sahip öğrencilerin İBDÖ puan ortalaması $100.8 \pm 1.081$ iken, geniş aileye sahip olanların puan ortalamas $198.0 \pm 2.029$ olarak belirlenmiştir. İki ortalama arasındaki farkın istatistiksel olarak anlamsız olduğu ortaya konulmakla birlikte ( $>0.05)$ (Şekil 5), öğrencilerin çekirdek aileye ya da geniş aileye sahip olmasının, onların iletişim becerileri üzerinde herhangi bir 
etkisinin görülmediği tespit edilmiştir. Çalışma bulgusu ile benzer şekilde, Bingöl ve Demir (2011)'in sağlı yüksekokulu öğrencileri ile yaptı̆̆ çalışmada da aile yapısı ile öğrencilerin İBDÖ puan ortalamaları arasında istatistiksel bir ilişki saptanmamıştır. Benzer şekilde, Kuzu ve Eker (2010)'in Hemşirelik bölümü öğrencileri ile yaptı̆̆ çalışmada da öğrencilerin ailelerine ilişkin özelliklerine göre İletişim Becerilerini Değerlendirme Ölçeği puan ortalamalarında istatistiksel olarak anlamlı bir fark olmadığı belirlenmiştir.

Öğrenciler anne eğitim durumuna göre değerlendirildiğinde, eğitim durumu ilköğretim olan grubun İBDÖ puan ortalaması $99.6 \pm 1.037$ iken, ortaöğretim olan grubun $105.0 \pm 3.568$ ve yükseköğretim olan grubun ise $101.8 \pm 3.244$ puan olarak belirlenmiştir. Anne eğitim durumuna göre İBDÖ puan ortalaması yüksekten düşüğe doğru ortaöğretim, yükseköğretim ve ilköğretim şeklinde sıralanmış ve gruplar arasındaki farkın istatistiksel olarak anlamsız olduğu belirlenmiştir ( $p>0.05$ ) (Şekil 6). Buna göre; anne eğitim durumu öğrencilerin iletişim becerilerini değerlendirmede etkisiz bulunmuştur. Çalışma bulgusu ile benzer şekilde, Bingöl ve Demir (2011)'in sağl1k yüksekokulu öğrencileri ile yaptı̆̆ çalışmada da annenin eğitim düzeyi ile öğrencilerin İBDÖ puan ortalamaları arasında istatistiksel bir ilişkki saptanmamıştır.

Çalışmaya katılan öğrenciler baba eğitim durumuna göre değerlendirildiğinde, eğitim durumu ilköğretim olan öğrencilerin İBDÖ puan ortalaması $99.8 \pm 1.047 \mathrm{iken}$, ortaöğretim olan öğrencilerin $100.1 \pm 2.709$ ve yükseköğretim olan öğrencilerin ise $104.2 \pm 2.577$ puan olarak belirlenmiştir. Baba eğitim durumuna göre İBDÖ puan ortalaması yüksekten düşüğe doğru yükseköğretim, ortaöğretim ve ilköğretim şeklinde sıralanmış ve gruplar arasındaki farkın istatistiksel olarak anlamsız olduğu belirlenmiştir ( $>0.05)$ (Şekil 7). Tıpkı anne eğitim durumunda sonuçlandığı gibi baba eğitim durumu da öğrencilerin iletişim becerilerini değerlendirmede etkisiz bulunmuştur. Çalışma bulgusu ile benzer şekilde, Bingöl ve Demir (2011)'in sağlık yüksekokulu öğrencileri ile yaptığı çalışmada da babanın eğitim düzeyi ile öğrencilerin İBDÖ puan ortalamaları arasında istatistiksel bir ilişki saptanmamıştır.

Çalışmaya katılan öğrenciler yaşadı̆̆ köyde yaşayan öğrencilerin İBDÖ puan ortalaması 100.1 \pm 1.691 iken, ilçede 
yaşayan grubun $100.3 \pm 1.865$ puan ve şehirde yaşayanların ise $100.1 \pm 1.468$ puan olarak belirlenmiştir. Belirlenen rakamlara göre öğrencilerin İBDÖ puan ortalamaları yaşadığ 1 yere göre istatistiksel olarak anlamlı bir farklılık göstermemektedir ( $>0.05$ ) (Şekil 8). Köyde ve ilçede yaşayanlara nazaran, şehirde yaşayanların lehine anlamlı bir fark çıkması beklenmekteyken, yaşanılan yer iletişim becerisi üzerinde etkisiz bulunmuştur. Çalışma bulgusu ile benzer şekilde, Acar (2009)'ın öğretmen adayları ile yaptığı çalışmada, adayların ailelerinin yaşadıkları yere göre, iletişim becerileri ölçeği toplam puanlarının ortalamaları ve alt boyutlara ait puanların ortalamaları arasında anlamlı bir fark bulunamamıştır.

\section{SONUÇLAR}

Örneklemin İBDÖ puanı 68 ile 123 arasında değişmekte olup örneklem ortalaması 100.2 \pm .956 puan olarak hesaplanmıştır. Birinci sınıf öğrencilerin İBDÖ puan ortalamaları 4. sınıfların ortalamasından yüksektir ancak aradaki fark anlamlı değildir. Kız öğrencilerin İBDÖ puan ortalaması erkeklerin puan ortalamasından anlamlı derecede yüksektir. Öğrencilerin yaş gruplarına, aile tiplerine, anne eğitim durumuna ve baba eğitim durumuna ve yaşadığı yere göre İBDÖ puan ortalamaları farklıl1k göstermemektedir.

$\mathrm{Bu}$ sonuçlar doğrultusunda;

Öğrencilerin iletişim becerileri ve etkileyen etmenlerin incelendiği başka çalışmaların yapılması, iletişim becerilerinin farklı örneklemlerin karşılaştırılması yolu ile çalışılması önerilmektedir. Ayrıca bu çalışmada 1 ve 4. Sınıf öğrencilerin iletişim becerilerinin farklılık göstermemesi üniversite öğrencilerinin müfredatlarının iletişim becerileri açısından yeniden ele alınması gerektiğini göstermektedir.

\section{KAYNAKÇA}

Acar, V. (2009). Öğretmen Adaylarının İletişim Becerileri. Mehmet Akif Ersoy Üniversitesi, Sosyal Bilimler Enstitüsü, Eğitim Bilimleri Anabilim Dalı. (Yüksek Lisans Tezi). 
Akbal, N. (2008). Etkili Okulun Oluşmasinda Okul Yöneticilerinin Etkin İletişsim Becerileri (Büyükçekmece Örneği). Beykent Üniversitesi, Sosyal Bilimler Enstitüsü, İşletme Yönetimi Anabilim Dalı, Eğitim Yönetimi ve Denetimi Bilim Dalı. (Yüksek Lisans Tezi)

Akbaş, F. (2018). Özel Okullarda, Okul Yöneticilerinin İletişim Becerileri ile Branş Öğretmenlerinin Motivasyonu Arasindaki İlişki. Bahçeşehir Üniversitesi Eğitim Bilimleri Enstitüsü. (Yüksek Lisans Tezi).

Albayrak, F. (2019). Sivas Numune Hastanesi'nde Çalışan Hemşirelerin Iletetşim Becerilerinin Motivasyon Ve Tükenmişlik Düzeyine Etkisi. Sivas Cumhuriyet Üniversitesi, Sosyal Bilimler Enstitüsü, Sağlık Kuruluşları Yöneticiliği Anabilim Dalı. (Yüksek Lisans Tezi).

Baran, A. (1997). İletişim Sosyolojisi. Ankara.

Başaran, E. (1999). Eğitime Giriş. Ankara: Umut Yayım-Dağıtım.

Başaran, E. (2000). Örgütsel Davranış. Ankara: Feryal Matbaası.

Baykara Pehlivan, K. (2005). Öğretmen Adaylarının İletişim Becerisi Algıları Üzerine Bir Çalışma. İlköğretim-Online. 17-23.

Bingöl, G., \& Demir, A. (2011). Amasya sağlık yüksekokulu öğrencilerinin iletişim becerileri. Göztepe Tip Dergisi, 152-159.

Ceylan, E. A. (2017). Okul Öncesi Öğretmenlerinin Çocuk Sevme Düzeyleri ile İletişim Becerileri Arasındaki İlişkinin İncelenmesi. Aksaray Üniversitesi, Sosyal Bilimler Enstitüsü, İlköğretim Anabilim Dalı, Okul Öncesi Eğitimi Bilim Dalı. (Yüksek Lisans Tezi)

Cüceloğlu, D. (2000). İyi düşün doğru karar ver. İstanbul: Sistem Yayıncıllk.

Cüceloğlu, D. (2016). Yeniden insan insana. İstanbul: Remzi Kitabevi.

Çağlar, İ., \& Kılıç, S. (2014). Genel, Teknik ve Etkili İletişim. Ankara: Nobel Akademik Yayınc1lk.

Çamdereli, M. (2008). İletişime Giriş. İstanbul: Dem Yayınları.

Çelik, Ç. (2007). İlköğretim Okulu Müdürlerinin İletişim Becerileri ile Tükenmişslik Düzeyleri Arasındaki İlişsi (Gaziantep İli Merkez İlçeleri Örneği). Gaziantep Üniversitesi Sosyal Bilimler Enstitüsü Eğitim Bilimleri Ana Bilim Dalı. (Yüksek Lisans Tezi).

Çetinkaya, Z. (2011). Türkçe Öğretmen Adaylarının İletişim Becerilerine İlişkin Görüşlerinin Belirlenmesi. Kastamonu Eğitim Dergisi , 567-576.

Çoraklı, Y. (2019). Hemşirelerin İletişim Becerilerinin İncelenmesi. Marmara Üniversitesi, Sosyal Bilimler Enstitüsü, Halkla İlişkiler ve Tanıtım Anabilim Dalı, Kişilerarası İletiş̧im Bilim Dalı. (Yüksek Lisans Tezi).

Dökmen, Ü. (1994). İletişim Çatı̧̧maları ve Empati. İstanbul: Sistem Yayıncılık. 
Duran, S. (2019). Sağlık Çalışanlarının İletişim Becerilerinin ve Göçmenlerle Yaşadıkları İletişim Zorluklarının Belirlenmesi. Yozgat Bozok ÜniversitesiKırıkkale Üniversitesi, Sağlık Bilimleri Enstitüsü, Hemşirelik Anabilim Dalı (Halk Sağlığı Hemşireliği). (Yüksek Lisans Tezi).

Erdoğan, İ. (2002). İletişimi Anlamak. Ankara: Pozitif Yayıncılık.

Erdoğan, İ., \& Alemdar, K. (1990). İletişim ve Toplum: Kitle İletişim Kuramları Tutucu ve Değişimci Yaklaşımlar. Ankara: Bilgi.

İnceoğlu, M. (2004). Tutum, algl, iletişim. Ankara: Elips Kitap.

Kayıç̧ı, K. (2001). Yönetici Yetiştirme Sorunu. Millı̂ Eğitim Dergisi .

Korkut, F. (1996). İletişim Becerilerini Değerlendirme Ölçeğinin Geliştirilmesi ve Geçerlilik Çalışmaları. Psikolojik Danışma ve Rehberlik Dergisi, 2(7), 18-23. Köleşoğlu, G. (2009). İlköğretim Öğretmenlerinin Liderlik Özellikleri ile İletişim Becerileri Arasındaki İlişki (İstanbul İli Beyoğlu İlköğretim Okullarında Bir Uygulama). Beykent Üniversitesi, Sosyal Bilimler Enstitüsü, İşletme Yönetimi Anabilim Dalı, Eğitim Yönetimi ve Denetimi Bilim Dalı. (Yüksek Lisans Tezi).

Kuzu, A., \& Eker, F. (2010). Hemşirelik Öğrencilerinin Duygusal Zekâ ve İletişim Becerilerinin Diğer Üniversite Öğrencileri ile Karşılaştırmalı Olarak Değerlendirilmesi. Hemşirelikte Araştırma Geliştirme Dergisi.

Küçük, M. (2012). İletişim Kavramı ve İletişim Süreci. Eskişehir: Anadolu Üniversitesi Yayınları.

Oskay, Ü. (1999). İletişimin abc'si. İstanbul : Der Yayınları.

Ökten, M. (2019). Hemşirelerin Duygusal Zekâ Düzeyleri ile İletişim Becerileri Arasındaki İlişkinin Incelenmesi. Beykent Üniversitesi, Sosyal Bilimler Enstitüsü, İşletme Yönetimi Anabilim Dalı Hastane ve Sağlık Kurumları Yönetimi Bilim Dalı. (Yüksek Lisans Tezi).

Tayfun, R. (2014). Etkili İletişim ve Beden Dili. Ankara: Nobel Akademik Yayıncılık. Taymaz, H. (2011). İlköğretim ve ortaöğretim müdürleri için okul yönetimi. Ankara: Pegem Yayıncilik.

Tutar, H., \& Y1lmaz, K. (2010). Genel iletişim kavramlar ve modeller. Ankara: Seçkin Yayıncilik.

Usluata, A. (1995). İletişim. İstanbul: İletişim Yayınları.

Ülker, Ç. (2016). Meslek Yükssekokulu Öğrencilerinin Sosyal Zekâ ve İletişim Becerilerinin Farklı Değişkenler Açısından Incelenmesi. Nişantaşı Üniversitesi, Sosyal Bilimler Enstitüsü, Psikoloji Anabilim Dalı. (Yüksek Lisans Tezi). 
Üstün, B., Akgün, E., \& Partlak, N. (2005). Hemşirelikte İletişim Becerileri Öğretimi. İzmir: Okullar Yayınevi.

YÖKSİS, (2019). https://yokatlas.yok.gov.tr/2016/lisans.php?y= 101310252 (son erişim tarihi 07.04.2019).

Zıllığlu, M. (1996). İletişim nedir? İstanbul: Cem. 